\title{
Foreign Financial Flows, Human Capital and Economic Growth in North African Countries
}

Received: 08.02.2021

Available online: 29.09.2021

\section{Imen Mohamed Sghaier}

\section{Abstract}

The purpose of this study is to analyze the relationship between foreign financial flows (i.e., FDI inflows and remittances), human capital, and its effects on economic growth in 4 North African countries. Annual panel data from 2000 to 2018 are examined using the system GMM. First, we found strong evidence of a positive link between FDI and economic growth. Moreover, the results indicate that the complementarity between FDI and human capital positively influences economic growth. Second, the remittances are found to be positive factors for economic growth. In fact, higher human capital accumulation of receiving countries increases these positive impacts. Overall, the results indicate that foreign financial flows are positively correlated with human capital in influencing economic growth in the North African countries. Therefore, it becomes pertinent for policymakers to pursue a human capital policy to improve their absorptive capacities to exploit full benefits of foreign financial flows.
Keywords: FDI, remittances, human capital, economic growth

JEL Classification: F24; N97; F35; F21

\section{Introduction}

In fact, foreign financial flows have been a major source of foreign exchange and external finance for all the developing countries. On the one hand, foreign direct investment (FDI) inflows play a vital role in promoting a country's position on the global platform by acting as a source of capital and technological know-how (Diaconu, 2014). Moreover, the multinational firms supply management experience, entrepreneurial abilities, and skills that are passed on to the local peers, and then carried on by the "learning by doing" process (Chuang, 1998). These positive spillovers amplify the growth of the economy. On the other hand, remittances have multiplier effects on consumption, improvement in financial intermediation, use of foreign exchange and hence enhance economic growth (Meyer and Shera, 2017).

Furthermore, economic performance across countries varies due to the determinants of economic growth, which differ from one country to another. In fact, economic growth is directly related to a few factors in all their

\footnotetext{
Higher Institute of Business Administration, University of Sfax, Tunisia.
} 


\section{Articles}

aspects, such as investment in physical and human capital, FDI, financial development and industrialization (Brooks et al. 2010). On the other hand, human capital development includes both qualitative and quantitative improvement and skill development in the labor force, which can be considered an important component that drives economic growth. Therefore, many African countries seeking productivity growth are likely to facilitate human capital development by attracting and promoting foreign capital inflows due to their limited budget for education, health, and social welfare, in the belief that productivity gains can be enhanced by developing their human capital (Asiamah et al. 2019). Theoretically, human capital is a precondition for attracting foreign financial flows, which increase the host countries' human capital accumulation and therefore improve economic growth.

As a result, we can affirm that the real effect of foreign financial flows on economic growth for the North African countries is driven by their interaction with human capital. From a policy perspective, this result is important because many North African countries remain heavily dependent on foreign financial flows to finance their economic development (Mowlaei, 2018). However, foreign financial flows to this region are on the decrease, which has heterogeneous impacts on economic growth (Adams and Klobodu, 2016) or even causes income inequality (Sharma and Abekah, 2017). Moreover, the absorptive effect of human capital on foreign financial flows is still a relevant topic of debate for the North African countries (Cleeve et al. 2015).

Therefore, this study examines the influence of foreign financial flows and human capital on economic growth and particularly the role of human capital in the relationship between foreign financial flows and economic
Foreign Financial Flows, Human Capital and Economic

Growth in North African Countries

growth in the North African countries. Unfortunately, empirical studies on the effect of the interaction of foreign financial flows and human capital on the economic growth of these countries are very limited. Furthermore, we investigate the associated growth effects of human capital and foreign financial forms, including FDI inflows and remittances. As such, we examine whether human capital can be a positive moderator for the effects of foreign financial flows on the North African countries' economic growth from the perspective that human capital stands for the absorptive capacity of host countries, as in the spirit of the endogenous growth theories (Tang and Zhang, 2016). It should also be noted that in the context of the Millennium Declaration era, the World Bank has been carrying out human capital projects in Africa to help the African countries strengthen their human capital, improve measurement and evidence, and promote knowledge exchange. In fact, the World Bank (2018) recognizes that investing in the African people is central to ensuring the continent's future prosperity and full participation in global markets.

This paper's contribution to the literature is threefold. First, it brings novel results to the empirical literature on the interactions between foreign financial flows and human capital concerning the previously ignored impacts. Second, in terms of policy implications, the outcome of this research will guide policymakers in designing policies aimed at encouraging the investment of the remittances in order to generate a significant economic benefit. Moreover, a policy similar to those created for FDI inflows could generate a higher positive impact of the remittances at the economic level. In effect this policy should encourage the use of the remittances as investments to ensure 


\section{Articles}

their contribution to a positive economic growth. Third, compared to previous studies, this paper uses a more advanced dynamic panel econometric technique that formally addresses the countries' specific effects and simultaneity bias. This method is based on the system Generalized Method of Moment (GMM) estimator, which has a number of advantages over the cross-section estimator.

The remainder of the article is structured as follows. Section 2 reviews some of the voluminous extant literature. Section 3 describes the data and the empirical methodology. The empirical results are presented in section 4 and finally section 5 draws the conclusions based on the results.

\section{Literature review}

\subsection{Human capital and economic growth}

Economists persistently advocate that human capital is a crucial element for economic growth regardless of the state of the economic conditions (see, Solow, 1956; Nelson and Phelps, 1966). With the emergence of new growth theories proposed by Lucas (1988), Romer (1986) and Barro (1997), human development has become one of the essential elements in promoting economic growth through technological innovation by reducing inequality and enhancing labor productivity because the presence of human capital in the economic structure enhances economic growth (Čadil et al. 2014). On the other hand, the productivity of manpower depends mainly on the knowledge and the skills possessed by the population, which can transform the population into manpower as productive input in the production function (Barro, 1991). Moreover, skilled manpower not only enhances productivity but also brings some dynamism in the economic activities. Human capital, therefore, is a potentially important factor in promoting economic growth.

In this context, Romele (2013) argued that the development of human capital needs a continuous substantial investment in capacity building through the implementation of the government's skill development programs and the improvement of the level of education of the workforce. In fact, human capital development positively influences the physical capital development in the economy, because investment in human development reduces the income inequality in the society (Heckman and Jacobs, 2010) and ensures a higher quality of the labor force for the economy and a sustainable economic growth in the long run (Deere and Vesovic, 2006). For his part, Lucas (1990) indicated that human capital is considered as a driver of economic growth for the developing countries.

In fact, over the past couple of decades, a large number of empirical studies have explored the positive association between human capital development and economic growth. For instance, Qadri and Waheed (2013) found a positive relationship between human capital and economic growth in a cross-sectional sample of 106 countries. As for Jaiyeoba (2015), he reported a positive association between human capital and economic growth in a study conducted on Nigeria. On the other hand, Pelinescu (2015) argued that there is a positive and significant association between human capital and economic growth in the European Union countries. For their part, Teixeira and Queiros (2016) analyzed the link between human capital and economic growth in the Organization for Economic Cooperation and Development countries, transition and Mediterranean counties and found that human capital exerts a positive and significant impact on economic growth. As for Fang and Chang 


\section{Articles}

(2016), they investigated the relationship between human capital and economic growth in 16 Asian Pacific countries and found a long-term link between human capital and economic growth. Recently, Ogundari and Awokuse (2018) have analyzed 35 countries across Sub-Saharan Africa (SSA) and showed a positive and significant association between human capital and economic growth.

\subsection{Foreign financial flows and human capital}

Human capital, which is embodied in the labor force, refers to skilled people with accumulated achievement, work experience and educational attainment. According to the endogenous growth theory, the model of productivity growth is considered as a function of educational levels or human capital. As for Mankiw et al. (1992), human capital is considered the average schooling years of the labor force. For his part, Romer (1990) suggested that human capital may directly affect productivity because it decides the capacity of countries to absorb new technologies, meaning that a highly educated labor force is a crucial determinant in creating, implementing and using new knowledge, thus promoting productivity growth (Benhabib and Spiegel, 1994).

On the other hand, Cohen and Levinthal (1990) introduced the notion of absorptive capacity as the firm's ability to value, assimilate and apply new knowledge to improve organizational learning. In fact, the notion of absorptive capacity refers to the ability of a recipient to assimilate the value and use the transferred knowledge. Therefore, the higher the absorptive capacities, the better the organization (for instance, a firm) is at understanding the acquired knowledge and thus unlocking and capturing the intrinsic
Foreign Financial Flows, Human Capital and Economic Growth in North African Countries

value of such knowledge and applying it for commercial purposes. As a consequence, human capital is the important factor for the development of absorptive capacity. Moreover, highly educated workers are the main drivers of knowledge acquisition because they maintain a high level of knowledge and have a greater ability to absorb new external knowledge and utilize it.

Furthermore, in the context of international integration, foreign financial flows can improve human capital and enhance economic growth in different ways. In general, foreign financial flows are accompanied by capital, transfer of technology and managerial knowledge directed to host countries. Hence human capital complements foreign financial flows as it makes them have a greater effect on economic growth. In this context Cohen and Levinthal (1990) considered internal and external knowledge as complementary since external capital inflows along with knowledge transfer have played a central role in the innovation process of the recipient countries. On the other hand, the internal ability is a prerequisite for using and assimilating sophisticated external knowledge (Lund Vinding, 2004). According to Arvanitis and Loukis (2009), the recipient country's human capital is considered an important driver not only for productivity but also for the absorptive capacity to mobilize foreign financial flows in promoting economic growth. Therefore, an improved human capital may play an essential role in improving economic growth through both direct and indirect effects as it is considered the catalyst of foreign financial flows. 


\section{Articles}

\subsection{Foreign financial flows, human capital and economic growth}

In fact, the link between foreign financial flows and macroeconomic issues is a popular topic in the specialized economic literature. According to Driffield and Jones (2013), foreign financial flows are considered an important resource in the productive growth process of countries facing financing constraints. In addition, foreign financial flows can influence the host country's economic growth through direct and indirect channels. As in the neo-classical theory, foreign capital can add to domestic investment and transfer new technologies, thus increasing economic growth as a direct effect. Regarding the indirect channel, many studies have investigated the capital inflows-growth relationship via the absorptive capacity of the recipient countries, which is principally measured by the accumulation of human capital.

\subsubsection{FDI, human capital and economic growth}

The evidence of the relationship between human capital and FDI remains mixed. On the one hand, human capital is one of the determinants of the location of FDI inflows. This relationship is demonstrated in many empirical studies in the literature. For instance, Borensztein et al. (1998) indicated that FDI supports economic growth if there is sufficient human capital in the host economy to absorb advanced technologies in developing countries. For their part, Noorbakhsh et al. (2001) stated that human capital in the host countries is a determinant of FDI inflows in the developing countries. These authors also revealed that human capital plays a significant role as it makes them recommend that the developing countries should formulate policies that improve local skills and build up their human resource capabilities. This is necessary to raise not only the volume but also the quality and sophistication of the FDI that a country can attract. In fact, Saggi (2000) reached similar policy conclusions when he found that without adequate human capital or investments in Research and Development (R\&D), spillovers from FDI will fail to materialize. This result highlights the importance of the countries' policies toward education, accumulation of human capital, and R\&D. As for Brooks et al. (2010), they showed that human capital positively affects FDI inflows, especially in skilled laborintensive sectors where the level of education could allow technological innovation and productivity improvement. Similarly, Reiter and S1teensma (2010) argued that FDI inflows into the developing countries are strongly affected by the human development of the host country. On the other hand, multinational companies can improve their operational efficiency and strengthen their competiveness by investing in a country that possesses a qualified manpower. Moreover, using the country's level of the panel data from 55 developing countries, Kheng et al. (2017) confirmed that FDI has a positive impact on economic growth when human capital development is taken into account by raising the spending on education and training. For their part, Li and Tanna (2019) found that the effect of FDI on economic growth depends on the promoted human capital accumulation in the developing countries. More recently, Abdouli and Omri (2020) have investigated the links between FDI inflows, human capital and economic growth in the Mediterranean region. Their results showed that there are bidirectional causal relationships between economic growth, FDI inflows, and human capital for all the considered panels. The authors 


\section{Articles}

also suggested that governments should be called to invest more in education which in turn, enhances economic growth through the research and development in innovation.

Other empirical findings revealed that there is no effect of human capital on FDI inflows. For instance, Gui-Diby (2014) affirmed that although human capital accumulation is limited, FDI inflows make a critical contribution to economic growth in the African region. Similarly, Cleeve et al. (2015) found that there is no evidence of the importance of human capital for FDI inflows mainly to the SSA. However, Kaulihowa and Adjasi (2019) declared that FDI failed to improve the accumulation of human capital in 9 African countries. More recently, Anetor Friday (2020) has found that FDI and human capital have no significant impact on economic growth in 28 SSA countries, while the interaction between FDI and human capital reduces economic growth, implying that SSA does not have a sufficient high-quality workforce that can absorb and transform the spillover benefits of FDI into economic growth.

\subsubsection{Remittances, human capital and economic growth}

Several empirical studies have tried to explain the macroeconomic determinants of remittance inflows. For instance, in their study on the main determinants of official remittances to 6 labor exporting countries in North Africa and Europe: Algeria, Morocco, Portugal, Tunisia, Turkey and Yugoslavia, Elbadawi and Rocha (1992) found that the remittances are closely associated with income cycles in the host countries, as well as with the length of stay and the massive immigration of workers. For their part, Nishat et al. (1993) identified the determinants of the remittances of the Pakistani immigrants to
Foreign Financial Flows, Human Capital and Economic Growth in North African Countries

the Gulf countries by stating that immigrant workers who possess high skills, good education and/or belong to urban areas tend to send more remittances compared to the uneducated and the unskilled workers. For his part, Poirine (1997) provided a further analysis of the remittances as an implicit family loan arrangement by considering these remittances as a repayment of educational costs. In other words, the remittances are a function of household use, which affects the economic growth of the host countries (Abbas et al. 2017). For their part, Ben Mim and Ben Ali (2012) examined the effects of the remittances on economic growth in 15 Middle East and North African countries and found that the remittances have a positive impact on economic growth only when they are invested besides; they are a growth enabler via human capital accumulation. As for $\mathrm{Di}$ Maria and Lazarova (2012), they studied the impact of the emigration of skilled workers on economic growth and human capital formation in some developing countries and found that it is statistically significant with regard to human capital formation, both on its level and composition. On the other hand, Buch and Kuckulenz (2010) argued that the level of education and skills also determines the expected wage of migrants. Hence highly educated migrants may earn a higher income and are likely to remit more. However, the link between the remittances and human capital is still mixed.

Regarding Bansak and Chezum (2009), they provided evidence from Nepal, in India, of a positive link between the remittances and the likelihood that children are enrolled in schools. They actually showed that higher relative net remittances, which show a larger effect of migration on relaxing budget constraints, are positively associated with the probability that 


\section{Articles}

children are at school. Using data from 122 developing countries, Azizi (2018) concluded that the remittances can increase investment in human capital, improve health outcomes and have a significant positive impact on education in the developing countries. As for Bouoiyour et al. (2016), they analyzed the relationship between the migrants' remittances and educational attendance in rural areas of southern Morocco. They found that the receipt of remittances has a significant positive effect on school attendance, especially for boys.

Overall the empirical literature on the relationship between the remittances and economic growth has not reached a consensus. For instance, the remittances are seen as complementary to domestic savings behavior and financial development, thus enhancing economic growth (Olayungbo and Quadri, 2019). On the other hand, Giuliano and Ruiz-Arranz (2009) revealed that the remittance inflows do not influence economic growth in a set of 73 developing countries. Moreover, Lim and Simmons (2015) found that there is no evidence of a longterm relationship between the remittances and economic growth or investment in the Caribbean Community and Common Market. The authors also suggested that the remittance inflows are used for consumption purposes rather than for productivity improving spending. In this context, Catrinescu et al. (2009) argued that the remittances will be more likely to contribute to economic growth in countries with higher quality political and economic policies and institutions. For their part, Huay et al. (2019) examined whether the increasing trend of remittances has an impact on human development in a broad range of the developing countries. They found that a rise in the remittance inflows is associated with improvements in human development.
They also argued that policymakers should devise public policies that promote income, health and education, to enhance human development. Similarly, Gnimassoun and Anyanwu (2019) examined the main channels through which the Diaspora influences economic development in Africa. In fact, these authors showed that the Diaspora positively and significantly contributes to economic growth in Africa. In addition, its effect increases with the level of education of emigrants. More recently, Bird and Choi (2020) have examined the impact of the remittances, FDI and foreign aid on economic growth in 51 low-income and middle-income developing countries. They found a negative relationship between the remittances and economic growth whereas FDI has a positive effect and the effect of foreign aid on economic growth is ambiguous.

Taken as a whole, the direct influence of foreign financial flows (i.e., FDI inflows and remittances) and human capital on economic growth are shown in the literature to be mixed, whereas their impact on the North African countries is attracting increasing attention among economists and other analysts. Notably, the combined effects of human capital and foreign financial flows on economic growth have been ignored in previous empirical research, which raises the question whether human capital can promote the growing effects of foreign financial flows on economic growth in the North African countries.

\section{Data and Empirical methodology}

\subsection{Data}

This paper considers a sample of 4 North African countries, namely, Tunisia, Morocco, Algeria and Egypt over the 2000-2018 period. 


\section{Articles}

The choice of the selected countries for this study is primarily dictated by the availability of reliable data over the sample period. The dependent variable is economic growth, which is measured as the growth rate of the real GDP per capita at 2010 USD prices. The main variable of interest (FDI inflows and remittances) and the other control variables are obtained from the World Development Indicators database (World Bank, 2021).

According to the World Bank, FDls are the net inflows of investment to acquire a lasting management interest (10 percent or more of voting stock) in an enterprise operating in an economy other than that of the investor. In fact, FDI is the sum of equity capital, reinvestment of the earnings, other long-term capital, and short-term capital as shown in the balance of payments. This series shows that the net inflows (new investment inflows less disinvestment) in the reporting economy from foreign investors are divided by GDP. We predict that FDI inflow positively impacts the economic growth of a country as it brings foreign capital and enhances the foreign exchange reserve (Anwar and Cooray, 2015).

On the other hand, the broader measure records the remittances as the sum of three aggregates: (1) Workers' remittances category which records current transfers to nonresidents by migrants who are employed in, and considered a resident of, the countries that host them. (2) Employee compensation category is composed of wages, salaries, and other benefits earned by individuals in countries other than those in which they are residents for work performed for and paid for by residents of those countries. (3) Migrants' transfers category comprises contra-entries to the flow of goods and changes in financial items that arise from individuals' change of residence from one country to another, such
Foreign Financial Flows, Human Capital and Economic

Growth in North African Countries

as movement of accumulated savings when a migrant returns permanently to the home country. Through positive influences on consumption, savings and investments, and by providing a catalyst for financial markets, remittances are expected to have a positive contribution to economic growth (Buch and Kuckulenz, 2010).

Therefore, the hypothesis that foreign financial flows affect economic growth is tested by estimating the dynamic panel data model for the GDP per capita growth over the 2000-2018 period. More specifically, we consider the most used variables in the empirical economic growth theory defined as follows:

- The initial GDP per capita (log): log of the real GDP per capita. A negative coefficient is expected, indicating the existence of conditional convergence among countries;

- Human capital is a key determinant of technology adoption as permitted by FDI. The effect of human capital is measured by tertiary school enrolment. Greater enrollment ratios lead to greater human capital, which should be positively associated with economic growth (Nyamongo et al. 2012). A positive coefficient is expected;

- Domestic investment (\% GDP) is viewed as a direct proxy of contribution to capital accumulation, as well as an indicator of efforts to develop basic economic infrastructure. It is defined as the ratio of gross fixed capital formation to GDP. A positive coefficient is estimated, as greater investment shares have been shown to be positively associated with economic growth (Mankiw et al. 1992);

- Trade openness measured by the ratio of the sum of goods exports plus goods imports as a share of GDP. Trade 


\section{Articles}

openness may contribute to economic growth through the diffusion of technical knowledge and the imports of high-tech items as well as through the spillover effects of foreign direct investment (Barro and Sala-i-Martin, 1997). A positive coefficient is expected.

Moreover, the extended model will include the following institutional variable:

- The economic freedom of the world index from the Fraser Institute is used to measure the freedom of economic activities in a country. The index measures institutional quality in five major areas namely: (i) size of government, (ii) legal structure and security of property rights, (iii) access to sound money, (iv) exchange with foreigners, and (v) regulation of capital, labor and business. The comprehensive area scores are all on a scale from zero to 10 , with zero being the least free and 10 the freest. In other words, the greater the economic freedom, the more it enhances economic growth (Azman-Saini et al. 2010). Therefore, a positive coefficient is expected. Besides, the data are obtained from Gwartney et al. (2020).

\subsection{Empirical methodology}

The purpose of our empirical analysis is to examine how human capital affects foreign financial flows and therefore economic growth in the North African countries. To this end, we employ a specification similar to that of Kheng et al. (2017) by considering the following model:

$$
\begin{aligned}
y_{i, t}= & \alpha y_{i, t-1}+\beta_{1} F \operatorname{Fin}_{i, t}+\beta_{2} H C_{i, t}+ \\
& +\beta_{3} X_{i, t}+\mu_{t}+\eta_{i}+\varepsilon_{i, t}
\end{aligned}
$$

Eq. (1) can also be alternatively written with the growth rate as a dependent variable as:

Growth $_{i, t}=y_{i, t}-y_{i, t-1}=(\alpha-1) y_{i, t-1}+\beta_{1}$ FFin $_{i, t}$ $+\beta_{2} H C_{i, t}+\beta_{3} X_{i, t}+\mu_{t}+\eta_{i}+\varepsilon_{i, t}$

The subscript " $t$ " represents the periods, whereas $i$ represents the country, $y$ is the logarithm of the real GDP per capita, FFin denotes foreign financial flows including FDI inflows and remittances, $\mathrm{HC}$ is the human capital and $X$ is the matrix of the control variables, $\mu_{t}$ is a time specific effect, $\eta_{i}$ is an unobserved country-specific fixed effect and $\varepsilon_{i, t}$ is the error term. Eq. (2) forms the basis for our estimation. $(\alpha-1)$ is the convergence coefficient.

While foreign financial flows (FFin) have the potential to affect the economic activity through a host of channels, in a second set of regressions, we examine one specific link between FFin and economic growth, specifically the one working through $\mathrm{HC}$. Hence the hypothesis we would like to check is whether the level of the human capital (HC) in the host country affects FFin and therefore economic growth. To this end, we add an interaction term constructed as the product of FFin and the $\mathrm{HC}$ (i.e., FFin* HC) to Eq. (2) as an additional explanatory variable, instead the standard variables used in the economic growth equation.

Then, we estimated Eq. (2) with an interaction term between foreign financial flows and the human capital variable 9as follows:

$\operatorname{Growth}_{i, t}=(\alpha-1) y_{i, t-1}+\beta_{1}$ FFin $_{i, t}+\beta_{2} H C_{i, t}+$
$\beta_{3}\left(\right.$ FFin $\left._{i, t} \cdot H C_{i, t}\right)+\beta_{4} X_{i, t}+\mu_{t}+\eta_{i}+\varepsilon_{i, t}$

1 There is extensive literature that looks at the role of institutions in economic growth. See, among others, Acemoglu et al. (2001) and De Haan (2007). 


\section{Articles}

The role of human capital in affecting foreign financial flows and hence, economic growth is assessed using the coefficient $\beta_{3}$. In fact, if $\beta_{3}$ is positive and statistically significant, an increase in human capital could improve the marginal effect of foreign financial flows on economic growth. This implies that there is a complementarity between foreign financial flows and human capital. On the other hand, if $\beta_{3}$ is negative and statistically significant, an increase in human capital could reduce the marginal effect of foreign financial flows on economic growth. In other words, a negative interaction provides evidence of substitutability between foreign financial flows and human capital.

To assert the effect that human capital has on foreign financial flows and hence, on economic growth, we focus on the effects of human capital and its interaction with foreign financial flows. Therefore, we apply the two-step system GMM estimator developed by Arellano and Bover (1995), and Blundell and Bond (1998), to estimate Eq. (3). In fact, there are two main reasons for choosing this estimator: the first is to exert control over country-specific effects, which cannot be done with country-specific dummies due to the dynamic structure of the regression equation, and the second is to exert control over a simultaneity problem caused by the possibility that some of the explanatory variables may be endogenous with growth or other dependent variables. Then, we analyze this endogeneity by using a two-step system GMM estimator for the estimation of dynamic unbalanced panel data. In the case of a strong endogeneity, the two-stage least squares (2SLS) method can be used. However, Lin and Lee (2010) showed that estimations provided by 2SLS are often weak in the presence of heteroscedasticity. In this context, the GMM is more effective (Lee,
Foreign Financial Flows, Human Capital and Economic

Growth in North African Countries

2007) besides, its estimators are well-known to treat situations in which explanatory variables are not strictly exogenous. Therefore, the traditional fixed effect estimator is incoherent because the mean of the lagged dependent variable is correlated with the idiosyncratic error term. As mentioned by Nickell (1981), this problem becomes particularly interesting in dynamic panel data models with relatively few time periods. In fact, a particular solution was proposed by Arellano and Bond (1991), Arellano and Bover (1995) and extended by Blundell and Bond (1998), who argued that the system GMM estimator will reduce the bias associated with the fixed effects in short panels and resolve the problem of endogeneity in dynamic panel data. Therefore, it is worth mentioning that a two-step system GMM estimator is asymptotically more efficient than a one-step estimator based on a sub-optimal weighting matrix. However, the former might produce a bias of uncorrected standard errors when the instrument count is high, implying that the number of instruments is less than the number of the cross-sections, which was highlighted by Roodman (2006).

The efficiency of the estimation of system GMM is based on the validity of two tests. First, the test of Sargan/Hansen, which enabled us to test the validity of the lagged variables and the second, is the test of Arellano and Bond where the null hypothesis is the absence of autocorrelation of errors in the second order difference equation.

\section{Empirical results}

The empirical results are presented in table 1 where column 1 reports a preliminary analysis on the effects of FDI inflows on economic growth then, column (2) presents the impacts of the remittances on economic growth. 
Articles

Table 1. The growth effect of foreign financial flows

\begin{tabular}{|c|c|c|}
\hline Variable & (1) & (2) \\
\hline Initial GDP per capita & $\begin{array}{c}-0.411^{* \star *} \\
(0.082)\end{array}$ & $\begin{array}{c}-0.455^{\star * *} \\
(0.104)\end{array}$ \\
\hline Human capital & $\begin{array}{c}0.205^{\star * *} \\
(0.093)\end{array}$ & $\begin{array}{l}0.28^{\star} \\
(0.141)\end{array}$ \\
\hline FDI & $\begin{array}{c}0.802^{\star * *} \\
(0.312)\end{array}$ & - \\
\hline FDI*Human capital & $\begin{array}{c}0.014^{* * *} \\
(0.005)\end{array}$ & - \\
\hline Remittances & - & $\begin{array}{l}0.251^{*} \\
(0.151)\end{array}$ \\
\hline Remittances*Human capital & - & $\begin{array}{l}0.010^{*} \\
(0.003)\end{array}$ \\
\hline Domestic investment & $\begin{array}{l}0.236^{*} \\
(0.123)\end{array}$ & $\begin{array}{l}0.173^{*} \\
(0.103)\end{array}$ \\
\hline Trade openness & $\begin{array}{l}0.131^{*} \\
(0.069)\end{array}$ & $\begin{array}{l}0.118^{*} \\
(0.065)\end{array}$ \\
\hline Index of economic freedom & $\begin{array}{l}0.184^{*} \\
(0.101)\end{array}$ & $\begin{array}{l}0.186^{*} \\
(0.102)\end{array}$ \\
\hline Constant & $\begin{array}{c}92.21 \\
(55.075)\end{array}$ & $\begin{array}{l}69.32 \\
(51.18)\end{array}$ \\
\hline AR(2) test (p-value) & 0.375 & 0.742 \\
\hline Hansen-J-Test (p-value) & 0.285 & 0.758 \\
\hline
\end{tabular}

Notes: The dependent variable is the growth rate of the real GDP per capita. The GMM is estimator in dynamic panel data models. Sample period 2000-2018. AR(2) is a test of second order residual serial correlation. J-test is the Hansen over identification test. p-values are in parentheses. ${ }^{*}{ }^{* *}$, and ${ }^{* * *}$ indicate statistical significance at $10 \%$, $5 \%$ and $1 \%$ levels, respectively.

The estimation results in table 1 show that the effect of human capital on economic growth is positive and significant in all cases of foreign financial flows. This result suggests that an increase of human capital in the North African countries would improve economic growth, which is in line with the result of Oketch (2006) and Ogundari and Awokuse (2018), who provided evidence that human capital makes a significant impact on economic growth in African countries. Besides, the positive nexus between FDI and economic growth is similar to that of the previous empirical studies of Borensztein et al. (1998) and Zekarias (2016), suggesting that FDI is an important vehicle for the transfer of technology since it contributes to technological progress and creates a spillover effect, and thereby raises the longterm growth rate. Moreover, we found that the FDI-human capital interaction effect is positive and significant with regard to economic growth. More specifically, the interaction term coefficient is 0.014 , implying that a $1 \%$ increase of the extent to which human capital absorbs FDI leads to a $0.014 \%$ increase of economic growth. We can therefore infer that human capital serves as a complementary factor to FDI in promoting economic growth, which is in line with the findings of Kheng et al. (2017) and Li and Tanna (2019). 


\section{Articles}

Just like FDI effects, we found that the effects of the remittances are positive and significant, suggesting that they enhance economic growth in the North African countries (see column 2). This result is in line with that of Chitambara (2019) and Egyir et al. (2020). Then, regarding the remittanceshuman capital interaction effect, we found a positive and significant coefficient. The implication of this result is that in the presence of human capital, the effect of the remittances on economic growth is improved in the North African countries, therefore we can infer that human capital and the remittances complement each other, which strengthens their effectiveness in promoting economic growth. Hence human capital seems to be an effective channel through which remittances stimulate economic growth in the region. This finding is in line with that of Bouoiyour et al. (2016) and Azizi (2018).

Most of the results regarding the other explanatory variables are in conformity with the expectations. The convergence theory is tested in this study using the lagged GDP per capita. In all the estimations it is found that the estimated coefficients are negative and significant at the conventional levels of testing. These results are consistent with the neoclassical model which postulates that the economy tends to approach its long run position if the starting per capita income is low. This result therefore supports the conditional convergence hypothesis in which case poor countries grow faster than richer countries. This finding corroborates the work of Barro and Sala-i-Martin (1997) and Sachs and Warner (1997). On the other hand, domestic investment has positive and statistically significant coefficients, indicating that greater domestic investment would promote economic growth. This assumption
Foreign Financial Flows, Human Capital and Economic

Growth in North African Countries

is supported by Adams (2009) and Eregha (2012). Moreover, it is shown that trade openness exerts a positive and significant influence on economic growth. This result is in line with that of the study of lamsiraroj (2016) and Sakyi et al. (2017) suggesting that larger openness to trade implies greater FDI inflows and therefore a positive impact on economic growth. Moreover, the index of economic freedom is included in the model in order to explain the impact of the institutional quality on economic growth, which is found to have a positive sign and statistically significant at conventional levels, considering that economic growth is stronger when economic freedom is high because it makes investment more productive. This finding is consistent with that of the survey conducted by Nawaz (2015) and Azman-Saini et al. (2010), who found that the improvement of the institutional quality leads to the acceleration of economic growth.

Importantly, the estimated regressions passed the specification tests. The $p$-values of second-order serial correlation and the $\mathrm{J}$-test indicate that the model is well specified and the instruments are valid.

\section{Conclusion}

To conclude, we can say that this paper investigates the relationship between foreign financial flows, and human capital and their effects on the economic growth in 4 selected North African countries over the 2000-2018 period. Empirical evidence is based on the system GMM estimators. The obtained results confirm that both foreign financial flows and human capital have a significant positive impact on economic growth. The results also suggest that foreign financial flows and human capital have a positive complementary effect on economic growth. We argue that the more the human capital improves, the 


\section{Articles}

more it attracts FDI and the remittances, which have a greater impact on economic growth. Furthermore, the results indicate that domestic investment, trade openness and economic freedom positively influence economic growth.

These insights have important policy implications to the extent that several North African countries still experience external financial or resource constraints and therefore, FDI and remittances can enhance economic growth. This is important if the benefits of FDI and the remittances, as well as the fact that they are less uncertain and a more stable source of a great deal of needed funds, are taken into account. Therefore, it becomes important for the North African governments to pursue a human capital policy to improve their absorptive capacities to exploit the full benefits of foreign financial flows. In addition, hard efforts should be made by policymakers to improve training and education of human capital, then, in the course of doing this, priority should be given to areas of knowledge and the skills needed by strategic sectors of the economy. Finally, they should create a good investment climate and economic policies that will not only improve the performance of multinational companies but also attract potential investors and help host countries reap full benefits from FDI and remittance inflows.

\section{References}

Abbas, F., Masood, A., and Sakhawat, A., (2017). "What determine remittances to Pakistan? The role of macroeconomic, political and financial factors", Journal of Policy Modeling, 39(3), 519-531.

Abdouli, M., and Omri, A., (2020). "Exploring the nexus among FDI inflows, environmental quality, human capital, and economic growth in the Mediterranean region", Journal of the
Knowledge Economy, https://doi.org/10.1007/ s13132-020-00641-5.

Acemoglu, D., Johnson, S., and Robinson, J., (2001). "The colonial origins of comparative development: An empirical investigation", American Economic Review, 91, 1369-1401.

Adams, S., (2009). "Foreign direct investment, domestic investment, and economic growth in sub-Saharan Africa", Journal of Policy Modeling, 31(6), 939-949.

Adams, S., and Klobodu, E.K.M., (2016). "Remittances, regime durability and economic growth in sub-Saharan Africa", Economic Analysis and Policy, 50, 1-8.

Anetor Friday, O., (2020). "Human capital threshold, foreign direct investment and economic growth: Evidence from sub-Saharan Africa", International Journal of Development Issues, 19, 323-337.

Anwar, S., and Cooray, A., (2015), "Financial flows and per capita income in developing countries", International Review of Economics and Finance, 35, 304-314.

Arellano, M., and Bond, S., (1991). "Some tests of specification for panel data: Monte Carlo evidence and an application to employment equations", Review of Economic Studies, 58(2), 277-297.

Arellano, M., and Bover, O., (1995). "Another look at the instrumental variable estimation of error-component models", Journal of Econometrics, 68(1), 29-51

Arvanitis, S., and Loukis, E.N., (2009). "Information and communication technologies, human capital, workplace organization and labor productivity: A comparative study based on firm-level data for Greece and Switzerland", Information Economics and Policy, 21(1), 4361.

Asiamah, M., Ofori, D., and Afful, J., (2019). "Analysis of the determinants of foreign direct investment in Ghana", Journal of Asian Business and Economic Studies, 26(1), 56-75. 


\section{Articles}

Azizi, S., (2018). "The impacts of workers' remittances on human capital and labor supply in developing countries", Economic Modelling, 75, 377-396.

Azman-Saini, W.N.W., Law, S.H., and Ahmad, A.H., (2010). "FDI and economic growth: new evidence on the role of financial markets", Economics Letters, 107(2), 211-213.

Bansak, C., and Chezum, B., (2009). "How do remittances affect human capital formation of school-age boys and girls?", American Economic Review, 99(2), 145-148.

Barro, R., (1991). "Economic growth in a cross section of countries", The Quarterly Journal of Economics, 106, 407-443.

Barro, R., (1997). Determinants of economic growth: A cross-country empirical study. Cambridge and London: MIT.

Barro, R.J., and Sala-i-Martin, X., (1997). "Technological diffusion, convergence, and growth." Journal of Economic Growth, 2(1), 1-27.

Ben Mim, S., and Ben Ali, M.S., (2012). "Through which channels can remittances spur economic growth in MENA countries?", Economics: The Open-Access, OpenAssessment E-Journal, 6, 1-27.

Benhabib, J., and Spiegel, M.M., (1994). "The role of human capital in economic development evidence from aggregate cross-country data", Journal of Monetary Economics, 34(2), 143173.

Bird, G., and Choi, Y., (2020). "The effects of remittances, foreign direct investment and foreign aid on economic growth: An empirical analysis", Review of Development Economics, 24, 1-30.

Blundell, R., and Bond, S., (1998). "Initial conditions and moment restrictions in dynamic panel data models", Journal of Econometrics, 87, 115-143.

Borensztein, E., Gregorio, J., and Lee, J., (1998). "How does foreign direct investment
Foreign Financial Flows, Human Capital and Economic Growth in North African Countries

affect economic growth", Journal of International Economics, 45(1), 115-135.

Bouoiyour, J., Miftah, A., and El Mouhoud, M., (2016). "Education, male gender preference and migrants' remittances: Interactions in rural Morocco", Economic Modelling, 57, 324331.

Brooks, D.H., Hasan, R., Lee, J.W., Son, H., and Zhuang, J., (2010). "Closing development gaps: challenges and policy options", Asian Development Review, 27(2), 1-28.

Buch, C. M., and Kuckulenz, A., (2010). "Worker remittances and capital flows to developing countries", International Migration, 48 (5), 89-117.

Čadil, J., Petkovová, L., and Blatná, D., (2014). "Human capital, economic structure and growth", Procedia Economics and Finance, 12, 85-92.

Catrinescu, N., Leon-Ledesma, M., Piracha, M., and Quillin, B., (2009). "Remittances, institutions, and economic growth", World Development, 37(1), 81-92.

Chitambara, P., (2019). "Remittances, institutions and growth in Africa", International Migration, 57(5), 56-70.

Chuang, Y.C., (1998). "Learning by doing, the technology gap, and growth", International Economic Review, 39(3), 697-721.

Cleeve, E.A., Debrah, Y., and Yiheyis, Z., (2015). "Human capital and FDI inflow: An assessment of the African case", World Development, 74, 1-14.

Cohen, W.M., and Levinthal, D.A., (1990). "Absorptive capacity: A new perspective on learning and innovation", Administrative Science Quarterly, 35(1), 128-152.

De Haan, J., (2007). "Political institutions and economic growth reconsidered", Public Choice, 127, 281-292.

Deere, D.R., and Vesovic, J., (2006). Chapter 6 educational wage premiums and the U.S. 


\section{Articles}

income distribution: A survey. In E. Hanushek \& F. Welch (Eds.), Handbook of the economics of education (pp. 255-306). USA: Elsevier.

Di Maria, C., and Lazarova, E.A., (2012). "Migration, human capital formation, and growth: An empirical investigation", World Development, 40(5), 938-955.

Diaconu, L., (2014). "The foreign direct investments in South-East Asia during the last two decades", Procedia Economics and Finance, 15, 903-908.

Driffield, N., and Jones, C., (2013). "Impact of FDI, ODA and migrant remittances on economic growth in developing countries: A systems approach", The European Journal of Development Research, 25(2), 173-196.

Egyir, J., Sakyi, D., and Baidoo, S.T., (2020). "How does capital flows affect the impact of trade on economic growth in Africa?", The Journal of International Trade and Economic Development, 29(3), 353-372.

Elbadawi, I.A., and Rocha, R., (1992). "Determinants of expatriate workers' remittances in North Africa and Europe", World Bank Working Papers, n¹038.

Eregha, P.B., (2012). "The dynamic linkages between foreign direct investment and domestic investment in ECOWAS countries: A panel cointegration analysis", African Development Review, 24(3), 208-220.

Fang, Z., and Chang, Y., (2016). "Energy, human capital and economic growth in Asia Pacific countries - Evidence from a panel cointegration and causality analysis", Energy Economics, 56, 177-184.

Giuliano, P., and Ruiz-Arranz, M., (2009). "Remittances, financial development and growth. Journal of Development Economics, 90, 144-52.

Gnimassoun, B., and Anyanwu, J.C., (2019). "The Diaspora and economic development in Africa", Working Paper Series, n’308, African Development Bank.
Gui-Diby, S.L., (2014). "Impact of foreign direct investments on economic growth in Africa: Evidence from three decades of panel data analyses", Research in Economics, 68(3), 248-256.

Gwartney, J., Lawson, R., Hall, J., and Murphy, R., (2020). Economic Freedom of the World-2020, Annual Report. Fraser Institute.

Heckman, J., and Jacobs, B., (2010). "Policies to create and destroy human capital in Europe", NBER Working Paper, n¹5742.

Huay, C.S., Winterton, J., Bani, Y. and Matemilola, B.T., (2019). "Do remittances promote human development? Empirical evidence from developing countries", International Journal of Social Economics, 46(10), 1173-1185.

lamsiraroj, S., (2016). "The foreign direct investment-economic growth nexus", International Review of Economics and Finance, 42, 116-133.

Jaiyeoba, S.V., (2015). "Human capital investment and economic growth in Nigeria", African Research Review, 9(1), 30-46.

Kaulihowa, T., and Adjasi, C., (2019). "Nonlinearity of FDI and human capital development in Africa", Transnational Corporations Review, 11(2), 133-142.

Kheng, V., Sun, S., and Anwar, S., (2017). "Foreign direct investment and human capital in developing countries: A panel data approach", Economic Change and Restructuring, 50(4), 341-365.

Lee, L.F., (2007). "GMM and 2SLS estimation of mixed regressive, spatial autoregressive models", Journal of Econometrics, 137, 489514.

Li, C., and Tanna, S., (2019). "The impact of foreign direct investment on productivity: New evidence for developing countries", Economic Modelling, 80, 453-466.

Lim, S., and Simmons, W.O., (2015). "Do remittances promote economic growth in the 


\section{Articles}

Caribbean Community and Common Market?", Journal of Economics and Business, 77, 4259.

Lin, X., and Lee, L.F., (2010), "GMM estimation of spatial autoregressive models with unknown heteroskedasticity", Journal of Econometrics, 157, 34-52.

Lucas, R., (1988). "On the mechanics of economic development", Journal of Monetary Economics, 22, 3-42.

Lund Vinding, A., (2004). Human resources; absorptive capacity and innovative performance. In Jesper, L.C., and Bengt-Ake, L. (Eds.), Product Innovation, Interactive Learning and Economic Performance. Bingley: Emerald Group Publishing Limited.

Mankiw, N.G., Romer, D., and Weil, D.N., (1992). "A contribution to the empirics of economic growth", The Quarterly Journal of Economics, 107(2), 407-437.

Meyer, D., and Shera, A., (2017). "The impact of remittances on economic growth: An econometric model", Economia, 18(2), 147155.

Mowlaei, M., (2018), "The impact of foreign capital inflows on economic growth on selected African countries", African Journal of Economic and Management Studies, 9(4), 523-536.

Nawaz, S., (2015). "Growth effects of institutions: A disaggregated analysis", Economic Modelling, 45, 118-126.

Nelson, R.R., and Phelps, E.S., (1966). "Investment in humans, technological diffusion, and economic growth", The American Economic Review, 56, 69-75.

Nickell, S., (1981). "Biases in dynamic models with fixed effects", Econometrica, 49, 14171426.

Nishat, M., Bilgrami, N., and Kazi, S., (1993). "The determinants of Worker's remittances in Pakistan", The Pakistan Development Review, 32(4), 1235-1245.
Foreign Financial Flows, Human Capital and Economic

Growth in North African Countries

Noorbakhsh, F., Paloni, A., and Youssef, A., (2001). "Human capital and FDI inflows to developing countries: New empirical evidence", World Development, 29(9), 15931610.

Nyamongo, E.M., Misati, R.N., Kipyegon, L., and Ndirangu, L., (2012). "Remittances, financial development and economic growth in Africa", Journal of Economics and Business, 64, 240-260

Ogundari, K., and Awokuse, T., (2018). "Human capital contribution to economic growth in Sub-Saharan Africa: does health status matter more than education? ", Economic Analysis and Policy, 58, 131-140.

Oketch, M.O., (2006). "Determinants of human capital formation and economic growth of African countries", Economics of Education Review, 25(5), 554-564.

Olayungbo, D.O., and Quadri, A., (2019). "Remittances, financial development and economic growth in Sub-Saharan African countries: Evidence from a PMG-ARDL approach", Financial Innovation, 5(9), 1-25.

Pelinescu, E., (2015). "The impact of human capital on economic growth", Procedia Economics and Finance, 22, 184-190.

Poirine, B., (1997). "A theory of remittances as an implicit family loan arrangement", World Development, 25(4), 589-611.

Qadri, F.S., and Waheed, A., (2013). "Human capital and economic growth: Cross-country evidence from low-, middle-and high-income countries", Progress in Development Studies, 13(2), 89-104.

Reiter, H. and Steensma, K., (2010). "Human development and foreign direct investment in developing dountries: The influence of FDI policy and corruption", World Development, 38 (12), 1678- 1691.

Romele, M.A.L., (2013). "Human capital development and economic growth in Latvia", European Scientific Journal, 9, 53-63. 
Romer, P., (1986). "Increasing returns and long-run growth", Journal of Political Economy, 94, 1002-1037.

Romer, P.M., (1990). "Endogenous technological change", Journal of Political Economy, 98(5, Part 2), S71-S102.

Roodman, D., (2006). "How to do xtabond2: An introduction to difference and system GMM in Stata", Center for Global Development Working Paper, n'103.

Sachs, J.D., and Warner, A.M. (1997). "Fundamental sources of long run growth", American Economic Review, 87, 184-188.

Saggi, K., (2000). "Trade, foreign direct investment, and international technology transfer: A survey", Policy Research Working Paper, n’2349. World Bank.

Sakyi, D., Villaverde, J., Maza, A., and Bonuedi, I., (2017). "The effects of trade and trade facilitation on economic growth in Africa", African Development Review, 29(2), 350-361.

Sharma, B., and Abekah, J., (2017). "Foreign direct investment, foreign aid and incomes inequality: Empirical insights from African and south American countries", Transnational Corporations Review, 9(1), 1-7.

Solow, R., (1956). "A contribution to the theory of economic growth", The Quarterly Journal of Economics, 70, 65-94.

Tang, Y., and Zhang, K.H., (2016). "Absorptive capacity and benefits from FDI: Evidence from Chinese manufactured exports", International Review of Economics and Finance, 42, 423-429.

Teixeira, A.A., and Queiros, A.S., (2016). "Economic growth, human capital and structural change: A dynamic panel data analysis", Research Policy, 45(8), 1636-1648.

World Bank, (2018). "The human capital project in Africa: Stories of progress", Washington, D.C.: World Bank Group.

World Bank (2021), World Development Indicators, World Bank, Washington DC.

Zekarias, S.M., (2016). "The impact of foreign direct investment on economic growth in Eastern Africa: Evidence from panel data analysis", Applied Economics and Finance, 3(1), 145-160. 